\title{
Drilling a Deep Geologic Test Well at Hilton Head Island, South Carolina
}

The U.S. Geological Survey (USGS), in cooperation with the South Carolina Department of Health and Environmental Control (SCDHEC), is drilling a deep geologic test well at Hilton Head Island, S.C. The test well is scheduled to run between mid-March and early May 2011. When completed, the well will be about 1,000 feet deep. The purpose of this test well is to gain knowledge about the regional-scale Floridan aquifer, an important source of groundwater in the Hilton Head area (fig. 1). Also, cores obtained during drilling will enable geologists to study the last 60 million years of Earth history in this area.

\section{Why Is the Drilling at Hilton Head Island?}

The USGS has undertaken a 5-year study of the geology of the greater Hilton Head region. This endeavor combines mapping of the surface geology with detailed study of the subsurface geology. The Hilton Head site was chosen to complete a series of test wells in Georgia and South Carolina that parallel the Savannah River from the Savannah River Nuclear Site to the Atlantic Coast. The data gathered from these wells will be combined with published information from other wells in the area to enable us to model the subsurface geology in this area.

\section{Why Are We Doing This Study?}

Groundwater is a vital natural resource in the southeastern Atlantic Coastal Plain. The Floridan aquifer, one of the most productive aquifers in the world, is a regional-scale source of groundwater that has been used locally for more than 100 years. Recently, heavy use of this resource has caused some wells along the coast to experience saltwater intrusion, rendering them unsuitable for drinking water (fig. 2). As water use increases in response to growing municipal, industrial, and agricultural demand, State and local governments will face difficult decisions about future use of the Floridan aquifer. A primary goal of the USGS is to make information on the aquifer available to decisionmakers. Defining the internal character and boundary of the aquifer in the subsurface requires detailed knowledge of the rock types, their ages, and their physical characteristics. This information will help water resource specialists to model groundwater flow and to correlate subsurface characteristics across State and local boundaries. The results from the test well at Hilton Head will be added to the larger database that describes the Floridan aquifer.

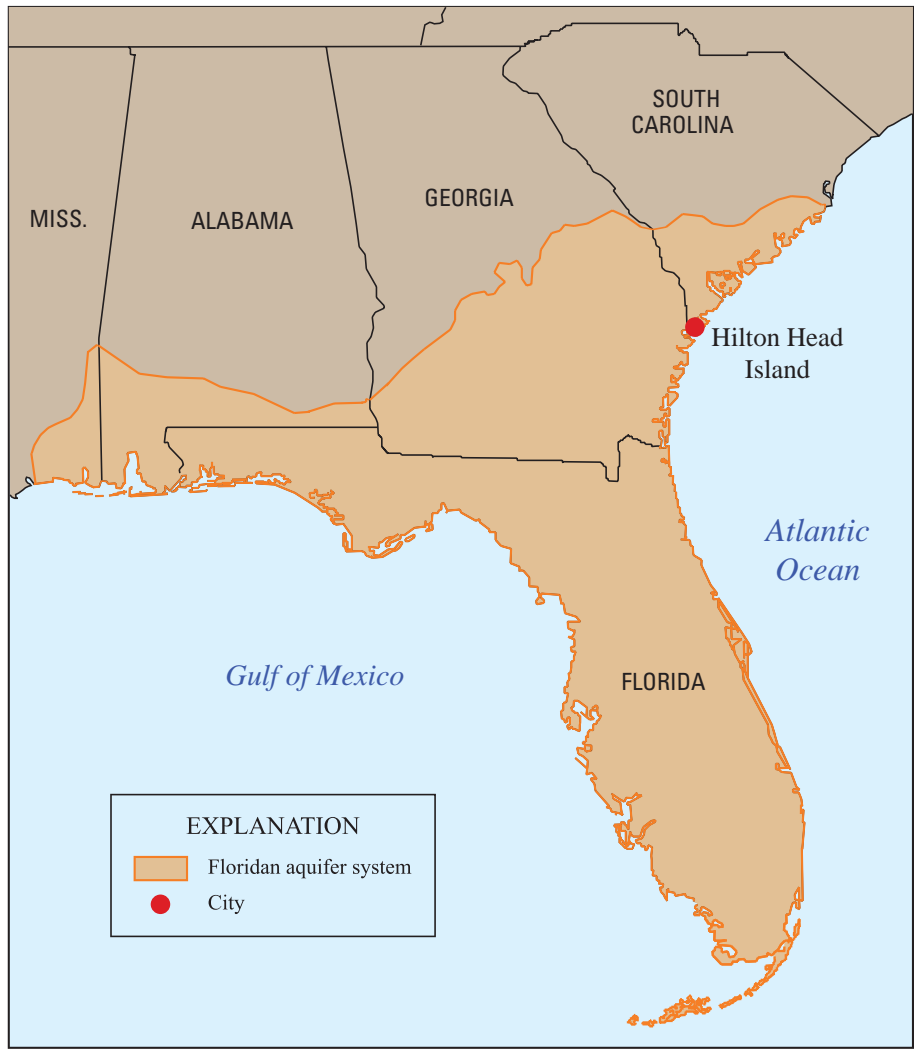

Figure 1. Extent of the Floridan aquifer. In the Savannah, Ga., area, the Floridan is about 400 feet thick and the top is about 200 feet below the surface. 


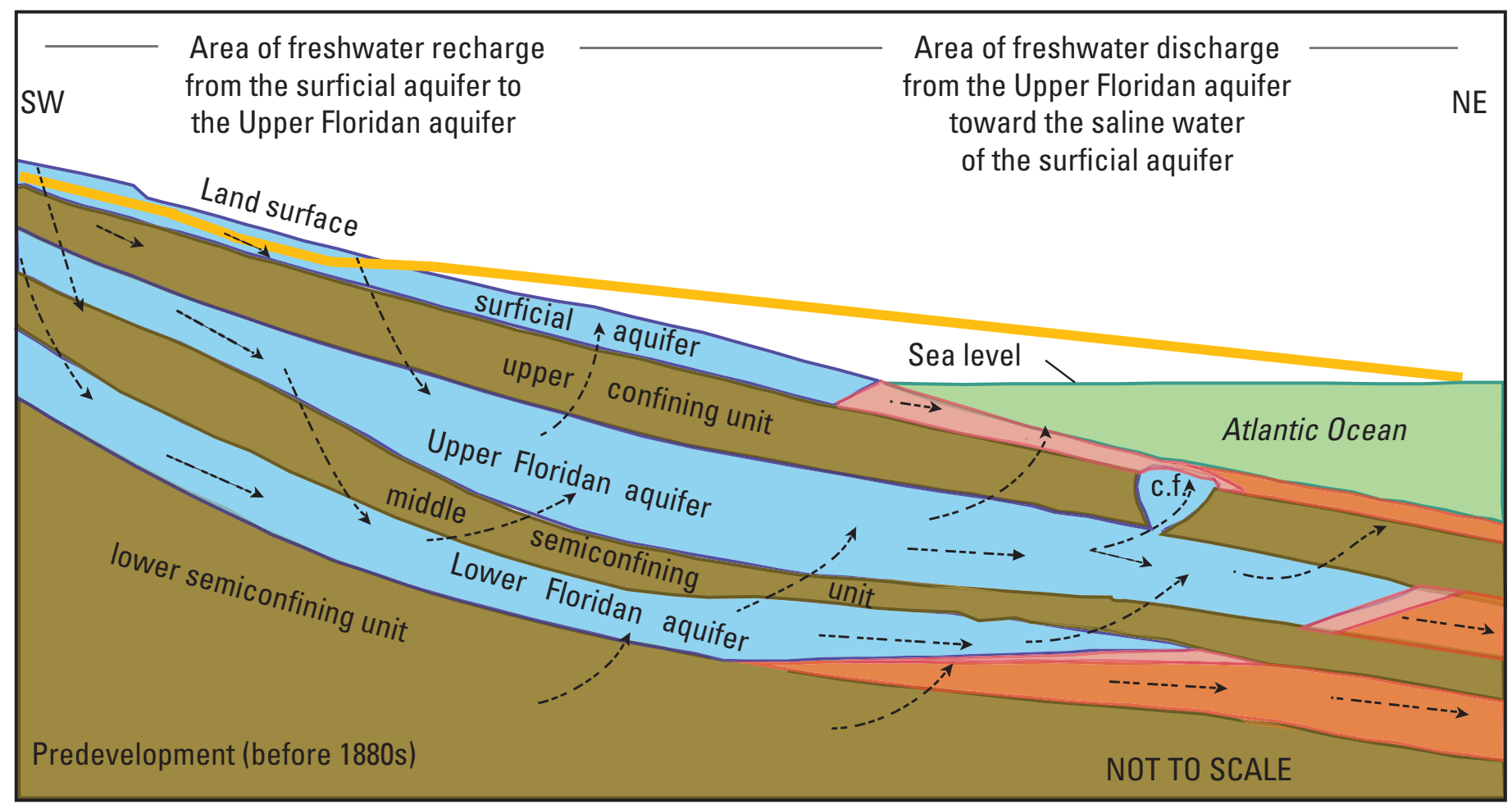

A

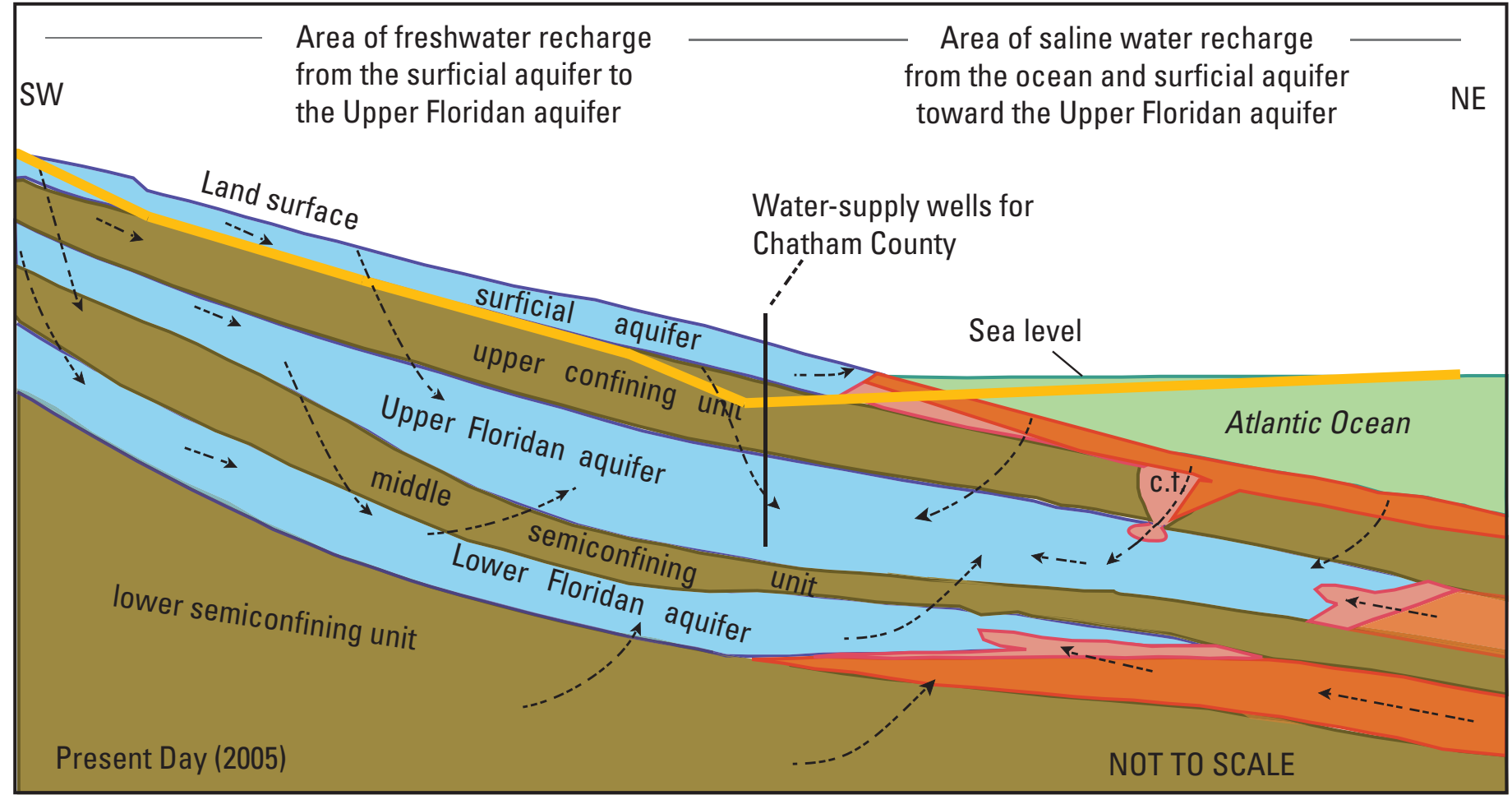

$B$

\begin{tabular}{|c|c|}
\hline \multicolumn{2}{|c|}{ EXPLANATION } \\
\hline Fresh groundwater & Potentiometric surface of \\
\hline Very saline groundwater & the Upper Floridan aquiter \\
\hline Moderately saline & $--\rightarrow \begin{array}{l}\text { General direction of } \\
\text { groundwater flow }\end{array}$ \\
\hline Seawater & Trace of cross section on \\
\hline Confining unit & [c.f., channel fill (permeable)] \\
\hline
\end{tabular}

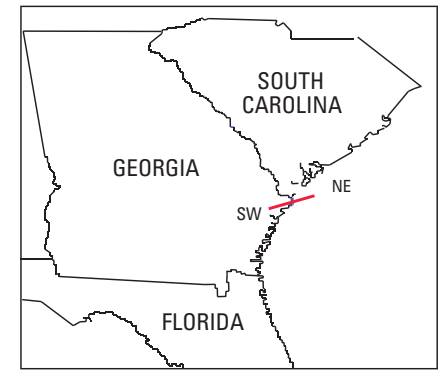

Figure 2. Floridan aquifer groundwater flow models. $A$, Before the 1880s; $B$, As of 2005. Modified from Falls and others, 2005. 


\section{What Exactly Are We Doing?}

The test well is obtained using a technology called wireline core drilling (fig. 3). A hollow drill stem (pipe) is carefully drilled through the soil into the underlying variably indurated sands, silts, clays, and limy sediments, which are collected in an inner core barrel in 10-foot sections. These sections are pulled back to the surface and the collected core is boxed for study (fig. 4). On site, the freshly cored sediments are described and sampled for laboratory analysis. The inner barrel is then put back down the hole to drill and collect the next 10-foot section. The Hilton Head test well will take about two months to drill. After the hole is completed, we will conduct a variety of tests in the open hole. These are referred to as "downhole geophysics" and involve lowering several instruments on cables in order to measure physical properties of the sand, silt, clay, and limy sediment layers such as electrical resistance and natural radiation. Finally, we will place a small groundwater monitoring instrument at a specific level in the hole and connect it to a surface graph. We will transport the collected core and samples back to USGS laboratories for completion of testing and descriptions. Paleontologists at the USGS will examine the core for microfossils that help explain the geologic history (fig. 5).

\section{What Will Be the Final Products of This Study?}

Following analysis of all the information gathered from the Hilton Head test well, the USGS will publish a set of reports and make them available to the public. These reports will include technical descriptions of the entire 1,000-foot corehole as well as assessments of fossil content, chemical characteristics, and ages of the sediments. This information will be correlated with data from other test wells in the Floridan aquifer. Information gathered from the groundwater monitoring instrument will be available as these data are accumulated.

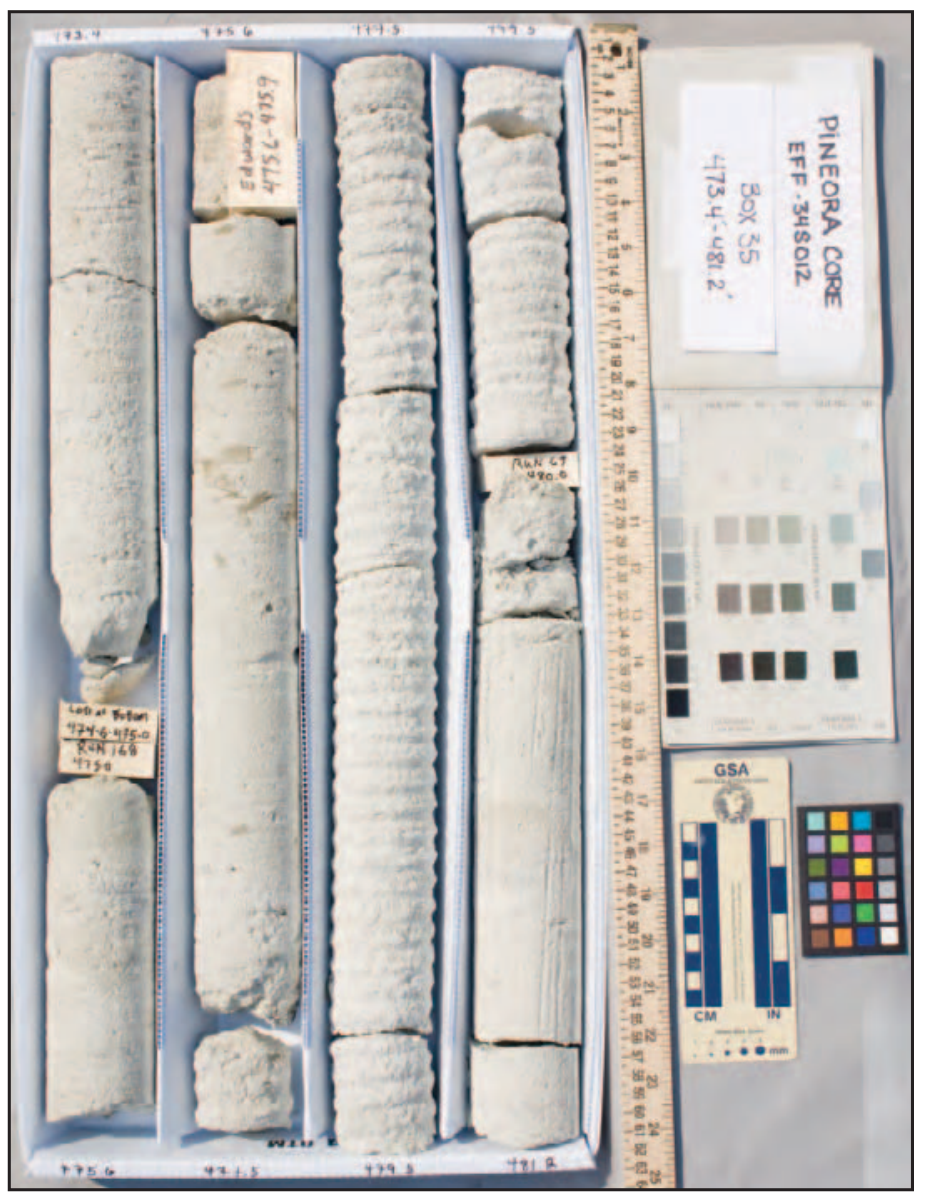

Figure 4. Section of poorly indurated limestone core recovered from a well drilled into the Floridan aquifer, Pineora, Ga. Box contains core from 473.4 to 481.2 feet down. This well was completed in April 2009 and is part of our USGS project work. Photograph by Colleen Durand, USGS.
Figure 3. U.S. Geological Survey drill rig and crew conducting wireline core drilling on the Atlantic Coastal Plain. 


\section{How Is the Drilling Funded?}

Funding for the Hilton Head test well comes from the USGS National Cooperative Geologic Mapping Program. This program is funded by Congress through the Department of the Interior and includes components that fund Federal, State, and academic research. Additional support comes from the SCDHEC. Funding covers all costs associated with drilling, salaries for science staff, and final publication of the results.

\section{Who Will Benefit From This Information?}

1. Federal, State, and local water management agencies

2. Environmental and geological consultants

3. State and local academic institutions

4. The general public

\section{Reference Cited}

Falls, W.F., Ransom, Camille, Landmeyer, J.E., Reuber, E.J., and Edwards, L.E., 2005, Hydrogeology, water quality, and saltwater intrusion in the Upper Floridan aquifer in the offshore area near Hilton Head Island, South Carolina, and Tybee Island, Georgia, 1999-2002: U.S. Geological Survey Scientific Investigations Report 2005-5134, 48 p. (available only at http://pubs.er.usgs.gov/usgspubs/sir/ sir20055134).

By Arthur P. Schultz and Ellen L. Seefelt
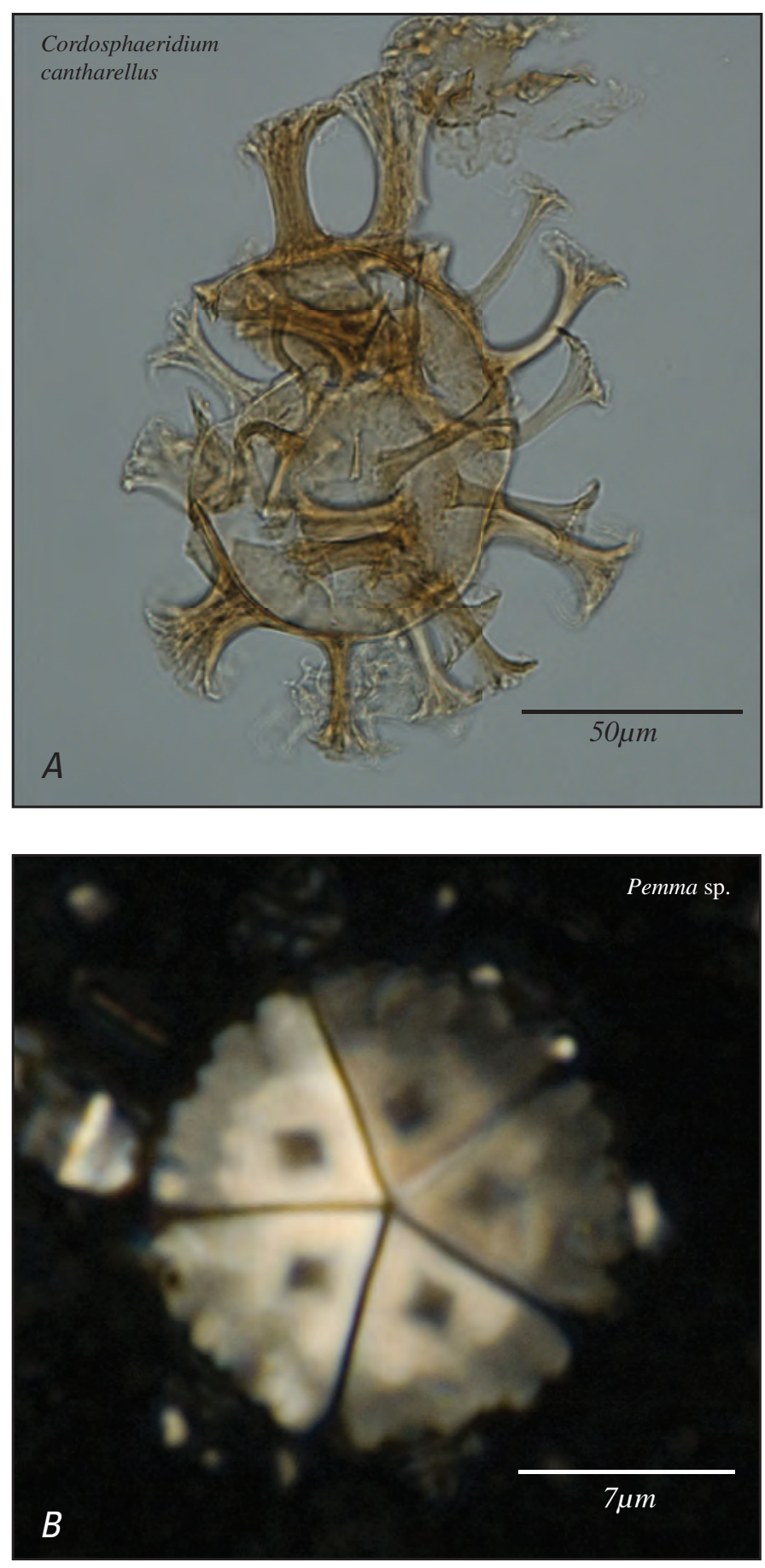

Figure 5. Photomicrographs of microfossils from the Atlantic Coastal Plain. $A$, Dinoflagellate; $B$, Calcareous nannofossil.

\section{For additional information, please contact:}

\section{Camille Ransom}

Department of Health and Environmental Control

2600 Bull Street

Columbia, SC 29201

Telephone: (803) 898-3575

E-mail: ransmoc@dhec.sc.gov
Art Schultz, Project Chief

U.S. Geological Survey

926A National Center

12201 Sunrise Valley Drive

Reston, VA 20192

Telephone: (703) 648-6501

E-mail: aschultz@usgs.gov 